\title{
Influence of hydraulic retention time on biogas production during leachate treatment
}

\author{
Souaâd Baâti ${ }^{1}$, Fatima Benyoucef ${ }^{2}$, Abdelhadi Makan ${ }^{3^{\dagger}}$, Abdelaziz El Bouadili ${ }^{1}$, \\ Abderrahmene El Ghmari ${ }^{2}$ \\ ${ }^{1}$ Laboratory of Industrial Engineering, Faculty of Sciences and Technics, 23000 Beni Mellal, Morocco \\ ${ }^{2}$ Team of Applied Teledetection and SIG to Geosciences and Environment, Faculty of Sciences and Technics, 23000 Beni Mellal, Morocco \\ ${ }^{3}$ Team of Water and Environmental Management (G2E), National School of Applied Sciences (ENSAH), University Mohamed 1st, 32003 Al-Hoceima, Morocco
}

\begin{abstract}
The main objective of this study is to investigate the influence of hydraulic retention time (HRT) on biogas production during leachate treatment using an anaerobic reactor type Upflow Anaerobic Sludge Blanket. For this purpose, four HRTs ranging from 12 to $48 \mathrm{~h}$ were experienced. The obtained results showed that higher amount of biogas could be produced during longer HRTs. However, HRTs longer than $48 \mathrm{~h}$ could not affect clearly the biogas generation and considered as unnecessary given the small additional amount of biogas produced during the degradation process. A volume of $0.434 \mathrm{~L} / \mathrm{L}_{\text {leachate }} / \mathrm{d}$ was achieved during the treatment with a HRT of $48 \mathrm{~h}$. The higher biogas production, the smaller chemical oxygen demand (COD) values achieved. Besides, COD removal and biogas production positively correlate, showing that the active biomass has degraded effectively the organic load to produce biogas. Moreover, all the analyzed physicochemical parameters have experienced a decrease after $48 \mathrm{~h}$ except for the $\mathrm{pH}$, which increased to approximately neutral value. More precisely, a decrease of $93.8 \%, 89.7 \%, 95 \%, 70 \%, 77 \%$, and $84.4 \%$ was recorded for COD, electrical conductivity, total suspended solid, turbidity, $\mathrm{NH}_{4}{ }^{+}-\mathrm{N}$, and $\mathrm{NO}_{3}{ }^{-}-\mathrm{N}$, respectively.
\end{abstract}

Keywords: Biogas production, Hydraulic retention time, Leachate, UASB reactor

\section{Introduction}

In Morocco, solid waste production is increasing steadily due to population growth and intensification of economic activities [1]. In 2014, the solid waste production is estimated to be 6.852 million tons per year of household wastes and 1.6 million tons per year of industrial wastes. The waste production rate varies from region to region and may vary from 0.3 in rural to 0.76 $\mathrm{kg} /$ capita/day in urban areas [2]. Particularly, household waste treatment remains very little developed except for composting and landfilling, almost universalized by the Moroccan communes [3]. The current landfilling practices can no longer continue in view of the considerable damage it causes to the environment, such as ground and surface water pollution, soil pollution, impact on human health and greenhouse gas emissions [4, 5]. The evolution of waste in landfills and their interactions with the external environment lead to percolation water and lixiviation issues. This water is loaded with organic and mineral substances and gives rise to leachates [6, 7]. Indeed, these leachates are rich in organic and inorganic matter, and heavy metals [8-10]. Their release into the natural environment is considered directly or indirectly harmful and threatening to the environment and public health.

The leachates as polluted effluents should be treated/managed to avoid negative environmental and/or sanitary impacts and meet the increasing requirements of discharged standards [11]. The Upflow Anaerobic Sludge Blanket (UASB) treatment technique has been used for anaerobic treatment of influents in many countries [12] generally at a temperature close to $20^{\circ} \mathrm{C}$ or beyond. However, this system can operate even under conditions where the average temperature is between 11 and $23^{\circ} \mathrm{C}$ although leachates may be cooler, especially in cold climate countries [13-16]. Garcia et al. [13] concluded that chemical oxygen demand (COD)
This is an Open Access article distributed under the terms of the Creative Commons Attribution Non-Commercial License (http://creativecommons.org/licenses/by-nc/3.0/) which permits unrestricted non-commercial use, distribution, and reproduction in any medium, provided the original work is properly cited.

Copyright (c) 2018 Korean Society of Environmental Engineers
Received December 2, 2017 Accepted March 2, 2018

${ }^{\dagger}$ Corresponding author

Email: abdelhadi.makan@gmail.com

Tel: +212-674-77-3636

ORCID: 0000-0003-0385-2498 
removal efficiency was not affected by temperatures between 15 and $35^{\circ} \mathrm{C}$. These promising results show that high-rate treatment at low temperature may minimize the need for heating the leachate prior to treatment, which may consequently provide an interesting cost-effective option for countries with cold climate [15].

The UASB technique is a promising anaerobic treatment that can achieve high treatment efficiency in short hydraulic retention time [17]. When submitted to high volumetric organic loading rate, UASB reactors have exhibited higher performances with respect to other kinds of anaerobic reactors [13]. Only a few researchers have been interested to study and improve/optimize the production of biogas from a UASB reactor. Nkemka and Murto [18] investigated the biogas production from wheat straw in batch and UASB reactors. They found that a high methane production rate was achieved from the hydrolysate, supplemented with nutrients, in a UASB reactor. The production of biogas could be enhanced by adding nutriments to the reactor [19], or using a specific type of microorganisms [20] in a specific range of temperature [21]. However, none of the literature studies has investigated the influence of hydraulic retention time (HRT) on the biogas production in a UASB system. The present work comes to enlighten this concern as a first step for studies that will follow. Quantitative analysis was carried out by monitoring the cumulative volume of biogas generated with different HRTs. Moreover, the treatment efficiency was assessed in terms of COD, pH, electrical conductivity (EC), total suspended solids (TSS), turbidity, $\mathrm{NH}_{4}{ }^{+}-\mathrm{N}$, and $\mathrm{NO}_{3}^{-}-\mathrm{N}$.

\section{Materials and Methods}

\subsection{Leachate Analysis}

Leachate considered in this work was collected from the packer-truck tank during household waste collection in the city of Kasba Tadla, Morocco. The annual production of household waste in the city was about 11,787 tons per year in 2013. This amount of waste generated a volume of 945,611 liters per year of young leachates [22], but no treatment is performed. Currently, several studies are undertaken to determine a suitable and cost-effective way to treat these leachates. The main physicochemical characteristic of the raw leachate used during experiments are shown in Table 1.

Table 1. Physicochemical Characteristics of Raw Leachate

\begin{tabular}{lccc}
\hline \multicolumn{1}{c}{ Parameter } & $\begin{array}{c}\text { Main } \\
\text { value }\end{array}$ & $\begin{array}{c}\text { Standard } \\
\text { deviation }\end{array}$ & Unit \\
\hline Temperature & 38.3 & 0.25 & ${ }^{\circ} \mathrm{C}$ \\
$\mathrm{pH}$ & 4.55 & 0.05 & - \\
Electrical conductivity (EC) & $15,436.7$ & 291.11 & $\mu \mathrm{s} / \mathrm{cm}$ \\
Total suspended solids (TSS) & $9,000.0$ & 660.0 & $\mathrm{mg} / \mathrm{L}$ \\
Turbidity & $2,836.7$ & 68.89 & $\mathrm{NTU}$ \\
$\mathrm{NH}_{4}{ }^{+}-\mathrm{N}$ & 45.7 & 2.89 & $\mathrm{mg} / \mathrm{L}$ \\
$\mathrm{NO}_{3}{ }^{-}-\mathrm{N}$ & 160.0 & 3.33 & $\mathrm{mg} / \mathrm{L}$ \\
$\mathrm{COD}$ & $24,450.0$ & 300.0 & $\mathrm{mg} / \mathrm{L}$ \\
\hline
\end{tabular}

\subsection{Analytical Methods}

The effluent from the UASB reactor was sampled periodically for COD, $\mathrm{pH}$, EC, TSS, turbidity, ammonium and nitrate nitrogen. Some measurements like $\mathrm{pH}$ and EC were carried out on site at the time of sampling, while other parameters were analyzed in the laboratory. All physicochemical parameters were determined according to standard methods of wastewater analysis [23]. EC and $\mathrm{pH}$ were measured in situ using an ORION 4 STAR conductivity meter and an Accumet AB15 pH-meter. The COD was determined according to potassium dichromate method, and TSS was measured using the centrifugation method. Measurement of turbidity was carried out by means of a spectrophotometer at $720 \mathrm{~nm}$. Finally, ammonium and nitrate nitrogen were determined also with a spectrophotometer in the visible type G BOYER/ANACHEM 320. All analyses were triplicated in order to ensure reproducibility and representativeness of the sample.

\subsection{Experimental Protocol}

The experimental protocol used in this study was composed of a buffer tank and the UASB reactor designed and used in Benyoucef et al. [22]. The reactor has an effective volume of 200 liters, and was designed to treat and handle about $1 / 10$ the amount of leachates daily produced in the city. Fig. 1 shows the modified scheme of the experimental protocol. A metallic colon linked to the digester ceiling enables the sludge-leachate-biogas separation. The first end of the metallic colon is immersed into leachate to a depth of $0.24 \mathrm{~m}$, while the second is used to collect biogas in a measuring cylinder filled with water and inverted over a trough of water at the head of each $2 \mathrm{~h}$.

Feeding the digester was performed continuously after a daily recuperation of leachate. Treatment efficiency was monitored by one-liter samples taken periodically from the buffer tank at the digester outlet. Samples were taken at different intervals, corresponding to HRTs of $12,24,36$ and $48 \mathrm{~h}$. The reactor was operated $10 \mathrm{~d}$ with a permanent flow for each HRT. Then, the samples were placed into plastic bottles, and were transported directly to the laboratory for analysis. The tests were replicated three times during three-month period from May to July 2015.

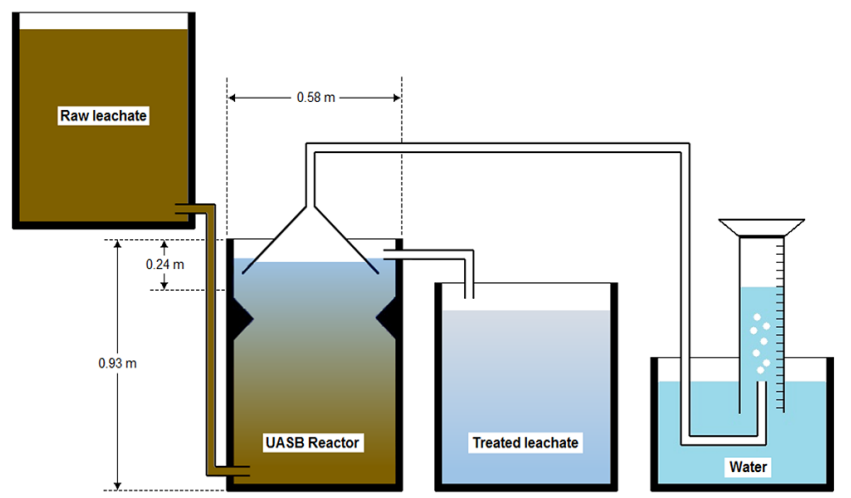

Fig. 1. Modified scheme of the experimental protocol. 


\section{Results and Discussions}

\subsection{Biogas Production}

As known, anaerobic biodegradation of organic materials produces biogas mainly methane and carbon dioxide [24]. For better understanding of the degradation process, both quantitative and qualitative analysis of generated biogas are required. The quantitative analysis is the primary focus of this work, while qualitative analysis will be the subject of further study.

Fig. 2 presents the evolution of biogas for different HRT. For all HRTs, the cumulative biogas production adopts a steadily increasing trend. The higher amount of biogas was produced with longer HRT since the microorganisms have been accorded much more time to actively degrade materials. Kaparaju et al. [21] reported that an increase in HRT might provide sufficient time for methanogens to mineralize the organic matter to methane and carbon dioxide. For example, after $12 \mathrm{~h}$, volumes of 0.11 , $0.16,0.21$ and $0.24 \mathrm{~L} / \mathrm{L}_{\text {leachate }}$ were achieved for HRT 12, HRT 24, HRT 36 and HRT 48, respectively.

The HRT is one of the most important parameters affecting the performance of a UASB reactor when used for the treatment of influents [25]. The upflow velocity is directly related with HRT and plays an important role to entrap suspended solids. A decrease in upflow velocity entails an increase in HRT, which boosts the removal efficiency of suspended solids detailed below $[26,27]$. The COD removal efficiency of a UASB reactor also decreases at elevated upflow velocity because higher velocity reduces the contact time between sludge and leachate in addition to smashing of sludge granules, and consequently higher washout of solids [28]. For instance, Nkemka and Murto [28] reported $81 \%$ COD removal efficiency at HRT of $12 \mathrm{~h}$ in a UASB reactor treating seaweed leachate, while Zhang et al. [29] reported 92\% COD removal efficiency at HRT of $10 \mathrm{~h}$ in a UASB reactor treating sewage. It is also important noticing that the volume of biogas produced towards the end of HRT 48 was insignificant. This suggests that the treatment is no longer effective and could be considered as waste of time and money. Such circumstances are justified by the amount of COD removal achieved.

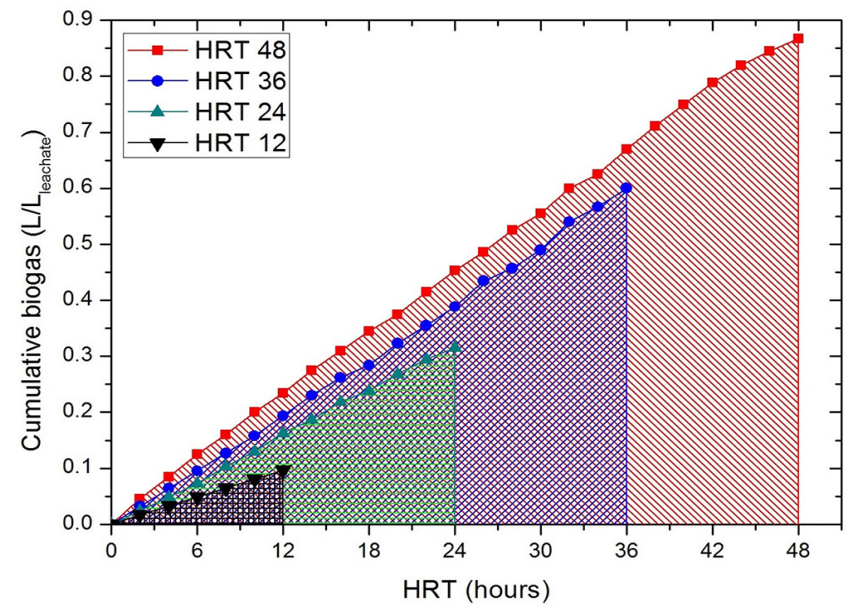

Fig. 2. Evolution of cumulative biogas in function of HRT.

\subsection{Treatment Efficiency}

In general, the treatment efficiency is monitored using different available and accessible physicochemical parameters. Those used in this study were limited to COD, pH, EC, TSS, turbidity, $\mathrm{N}-\mathrm{NH}_{4}{ }^{+}$, and $\mathrm{N}^{-\mathrm{NO}_{3}}{ }^{-}$.

\subsubsection{Evolution of $\mathrm{COD}$ and biogas}

COD is the most used parameter to assess and evaluate treatment efficiency, and it is highly related to the production of biogas as it represents the organic load included in the influent [30]. The biogas valorization as source of energy depends directly on its concentration. The content of COD found in Kasba Tadla fresh leachate was around 24,450 mg/L. Kaparaju et al. [21] claimed that the recuperation of energy is feasible in UASB reactor at an organic loading rate of $17.1 \mathrm{~g}-\mathrm{COD} /(\mathrm{l} . \mathrm{d})$ within $2 \mathrm{~d}$ hydraulic retention time. The Fig. 3(a) shows the evolution of COD content and biogas in function of HRT. It is clear from the curves that the evolution of COD in the effluent is inversely proportional to the evolution of produced volume of biogas. Otherwise, the COD removal is proportional to biogas yield. By increasing the HRT, the decline in COD content was accompanied by an increase of the amount of biogas formed. With
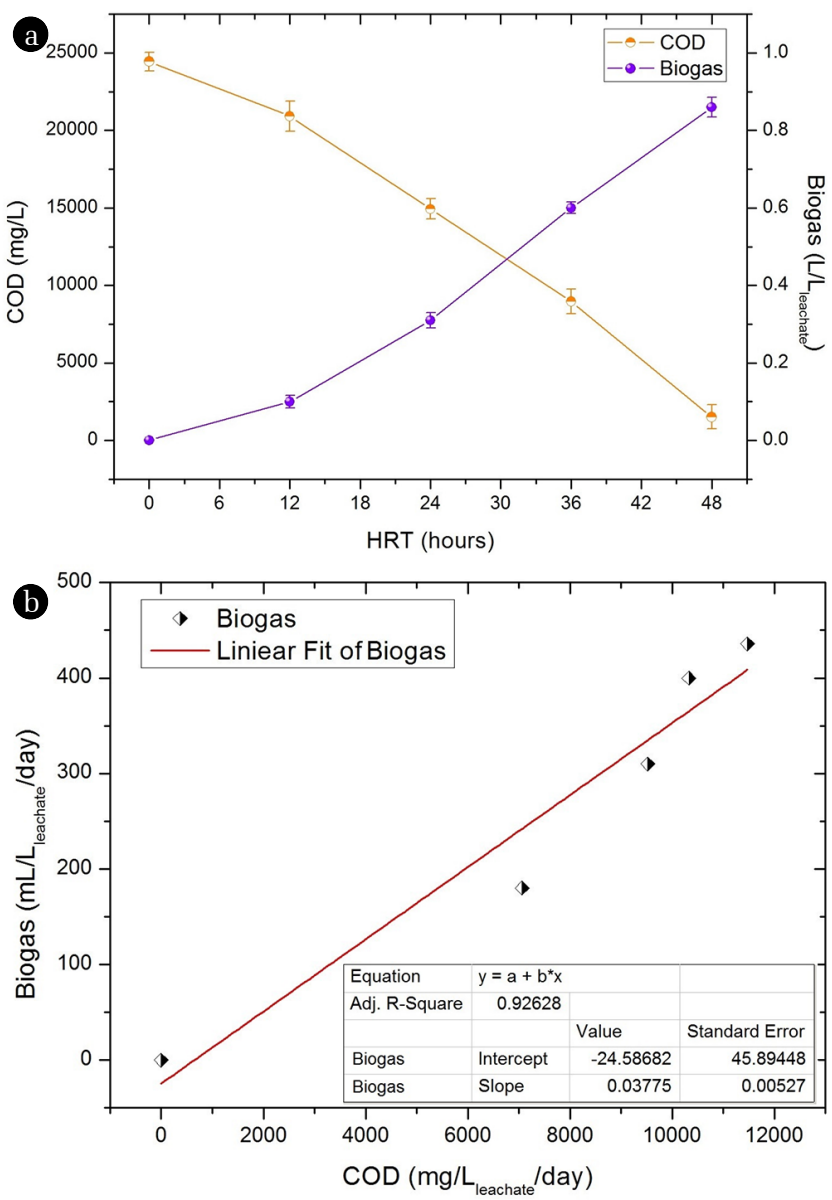

Fig. 3. (a) Evolution of COD and biogas in function of HRT, (b) Correlation between biogas production per day and COD removal per day. 
HRT 48, an organic load of 22,944 mg/L could be converted into $0.86 \mathrm{~L} / \mathrm{L}_{\text {leachate }}$ of biogas, giving rise to $93.8 \%$ of treatment efficiency in terms of COD removal. The correlation between biogas production per day and COD removal per day is presented in Fig. 3(b). It is noticed that the tow parameters positively correlate, showing that the active biomass has degraded effectively the organic load to produce biogas. The regression coefficient in Fig. 3(b) represents the mean change in biogas volume for one unit of change in COD removal. The equation shows that the coefficient for COD removal in $\mathrm{mg} / \mathrm{L}_{\text {leachate }} / \mathrm{d}$ is about $0.038 \mathrm{~mL} / \mathrm{L}_{\text {leachate }} / \mathrm{d}$. Otherwise, the coefficient indicates that for every additional gram in COD removal, we can expect biogas to increase by an average of $38 \mathrm{~mL}$. However, this relationship is only valid within the range of HRT of $48 \mathrm{~h}$ or around.

\subsubsection{Evolution of $\mathrm{pH}$ and $\mathrm{EC}$}

The evolution of $\mathrm{pH}$ and EC in function of HRT is presented in Fig. 4. From this figure, the $\mathrm{pH}$ of raw leachate was about 4.55, showing that the influent is already in the acidogenesis phase. This is due to the hydrolysis of complex organic polymers, which are reduced to simple soluble molecules such as amino acids, long-chain fatty acids, and sugars [31]. At the end of treatment, $\mathrm{pH}$ value rises increasingly according to the increasing HRTs. The $\mathrm{pH}$ reached 5.75, 6.40, 6.85 and 7.15 with HRT 12, HRT 24, HRT 36 and HRT 48, respectively. A neutral $\mathrm{pH}$ value is obtained with the high HRT of $48 \mathrm{~h}$. This increase in $\mathrm{pH}$ values could be explained by the conversion of organic acids to acetate, carbon dioxide, and hydrogen, which are consumed by methanogenic bacteria to produce methane [32].

The raw leachate had also an initial EC of 15,436.7 $\mu \mathrm{s} / \mathrm{cm}$. After different HRT of treatment, the EC value has been reduced progressively. This reduction reached 69\%, 77\%, 86\% and 90\% with an HRT of 12, 24, 36 and 48 h, respectively (Fig. 4). The decrease in EC value with HRT 48 was more remarkable since the medium took sufficient time to neutralize. This remarkable decrease is explained by the volatilization of ammonia and the precipitation of mineral salts [33].

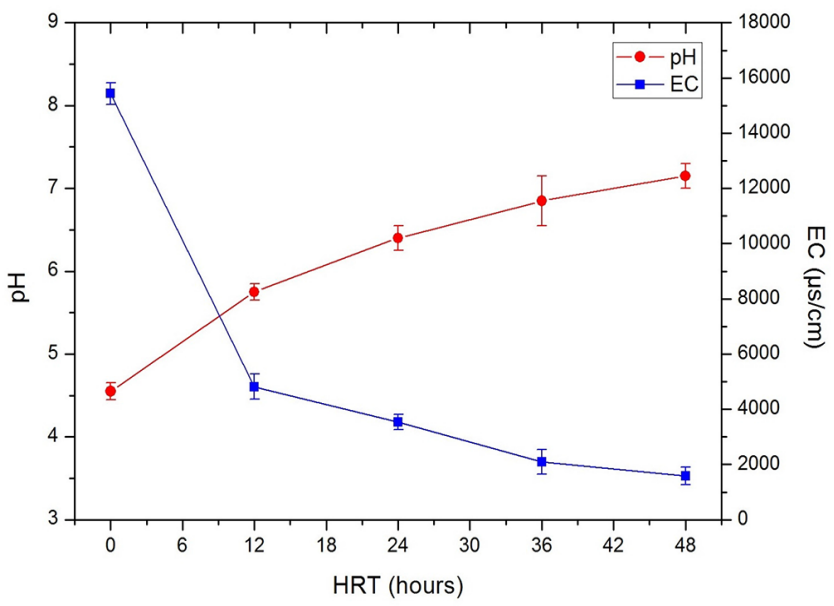

Fig. 4. Evolution of $\mathrm{pH}$ and $\mathrm{EC}$ in function of HRT.

\subsubsection{Evolution of TSS and turbidity}

The Fig. 5 illustrates the evolution of TSS and turbidity in function of HRT. The initial TSS content in raw leachate was 9,000.0 $\mathrm{mg} / \mathrm{L}$. There was an overall decrease in TSS content as the HRT increased. The decrease in TSS content continued up to 3,500, 1,500, 883 and $450 \mathrm{mg} / \mathrm{L}$, respectively for HRT 12, HRT 24, HRT 36 and HRT 48. The significant decrease in the TSS concentration for HRT 48 may be an indication of the active biomass growth in the reactor as more than $90 \%$ of volatile suspended solids contents are due to active biomass, and remaining $10 \%$ are attributed to non-biodegradable volatile solids and dead cell debris [34].

As given in Table 1, the raw leachate turbidity was 2,836.7 NTU. After different treatment by changing the HRT, the best removal efficiency of $70 \%$ was achieved at HRT 48. From Fig. 5 , it is deduced that the turbidity decreases by increasing the HRT. The decrease in turbidity refers to the decrease in suspended solids and this is due, in its turn, to the sedimentation of these particles after equalizing their ions. The equalizing ions drop down by gravity under the force of their own weight [35]. Gerardi [32] found a quit better result in a pilot-plant where the achieved removal efficiency was $82.0 \%$. Whereas, in a study carried out by Iglesias et al. [36], the turbidity removal was as high as $90 \%$ for the complete sequential anaerobic-aerobic treatment process.

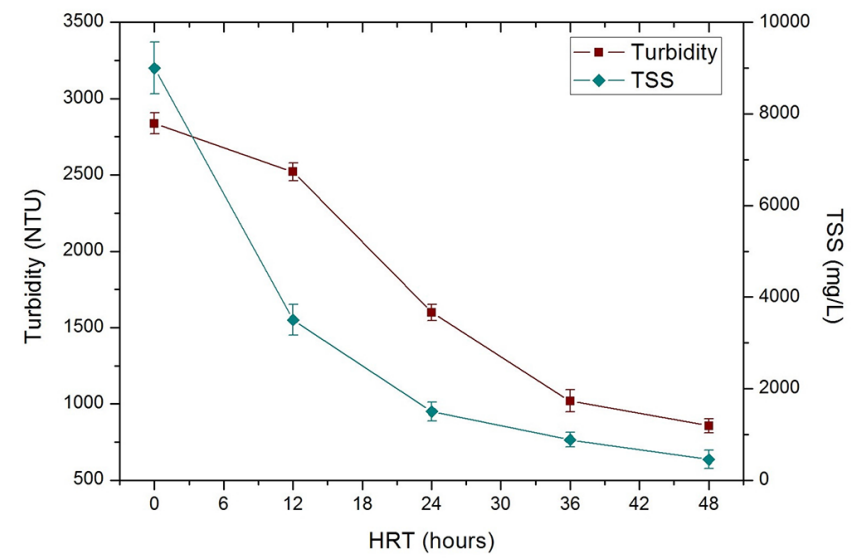

Fig. 5. Evolution of TSS and turbidity in function of HRT.

\subsubsection{Evolution of ammonium and nitrate}

The treatment started up with ammonium and nitrate nitrogen contents of about 45.7 and $160.0 \mathrm{mg} / \mathrm{L}$, respectively. One of the reasons why nitrate content is much higher than ammonium content could be the oxidation of ammonia into nitrate in the environment by two groups of chemo-lithotrophic bacteria which operate in sequence [37]. The Fig. 6 shows that $\mathrm{NH}_{4}{ }^{+}-\mathrm{N}$ and $\mathrm{NO}_{3}{ }^{-}-\mathrm{N}$ contents evolved in a parallel tendency in function of HRT. Both of them undergo progressive decrease with increasing HRT. The highest $\mathrm{NH}_{4}{ }^{+}-\mathrm{N}$ and $\mathrm{NO}_{3}{ }^{-} \mathrm{N}$ removals were achieved after an HRT of $48 \mathrm{~h}$. They reached 10.5 and $25 \mathrm{mg} / \mathrm{L}$ for ammonium and nitrate nitrogen respectively. The relatively low $\mathrm{NH}_{4}{ }^{+}-\mathrm{N}$ removal efficiency could be attributed to the utilization of $\mathrm{NH}_{4}{ }^{+}-\mathrm{N}$ through the assimilation of anaerobic bacteria as 


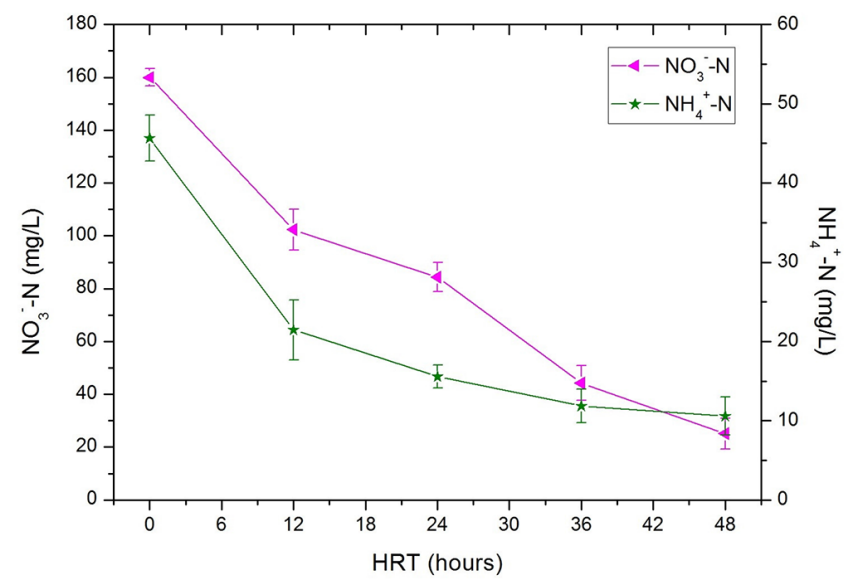

Fig. 6. Evolution of $\mathrm{NH}_{4}{ }^{+}-\mathrm{N}$ and $\mathrm{NO}_{3}{ }^{-} \mathrm{N}$ in function of HRT.

reported in some other publications [38, 39]. However, the decline in nitrate content is probably due to heterotrophic denitrification, which requires anoxic conditions in order to reduce nitrate to nitrite and subsequently to nitrogen gas [40].

\section{Conclusions}

This study showed that the use of leachate as source of renewable energy in form of biogas is feasible through the UASB technique. This technique proved to be suitable to the economic and environmental conditions for a country such Morocco. Besides, the climatic conditions are most favorable to effectively operate the UASB reactor without the need of heating. The HRT in the UASB reactor showed a significant influence on the conversion of organic load and, therefore, the production of biogas. However, after an HRT of $48 \mathrm{~h}$, the biogas production becomes ineffective and may be considered as waste of time and money with respect to the additional amount of biogas gained. A volume of 0.434 $\mathrm{L} / \mathrm{L}_{\text {leachate }} / \mathrm{d}$ was achieved during the treatment with an HRT of $48 \mathrm{~h}$. Finally, after only $48 \mathrm{~h}$, the UASB reactor proved to be effective in terms of all reported physicochemical parameters, especially in terms of COD removal, which reached 93.8\%. The performance of this technique could be further improved through the addition of certain natural source of nutriments, which can be supplied locally. Indeed, this will be the primary focus of a complementary subsequent study.

\section{References}

1. Makan A, Assobhei O, Mountadar M. Initial air pressure influence on in-vessel composting for the biodegradable fraction of municipal solid waste in Morocco. Int. J. Environ. Sci. Technol. 2014;11:53-58.

2. Giz. Rapport sur la gestion des déchets solides au MAROC. Deutsche Gesellschaft für Internationale Zusammenarbeit (GIZ) GmbH, Deutschland; 2014.

3. Chofqi A, Younsi A, Lhadi E, Mania J, Mudry J, Veron A.
Lixiviat de la décharge publique d'El Jadida (Maroc): Caractérisation et étude d'impact sur la nappe phréatique. Déchets Sci. Tech. 2007;46:4-10.

4. Chtioui H, Khalil F, Souabi S, Aboulhassan M. Evaluation de la pollution générée par les lixiviats de la décharge publique de la ville de Fés. Déchets Sci. Tech. janvier 2008;49:25-28.

5. Er-Raioui H, Bouzid S, Khannous S, Zouag MA. Contamination des eaux souterraines par le lixiviat des décharges publiques: Cas de la nappe phréatique R'Mel (Province de Larache-Maroc Nord-Occidental). Int. J. Biol. Chem. Sci. 2011;5:1118-1134.

6. Abbou MB, El Haji M, Zemzami M, Fadil F. Impact des lixiviats de la décharge sauvage de la ville de Taza sur les ressources hydriques (Maroc). Afr. Sci. Rev. Int. Sci. Technol. 2014;10:171-180.

7. El Bada N, Assobhei O, Kebbabi A, Mhamdi R, Mountadar M. Caractérisation et prétraitement du lixiviat de la décharge de la ville d'Azemmour. Déchets Sci. Tech. 2010;58:30-36.

8. Baun A, Ledin A, Reitzel LA, Bjerg PL, Christensen TH. Xenobiotic organic compounds in leachates from ten Danish MSW landfills - Chemical analysis and toxicity tests. Water Res. 2004;38:3845-3858.

9. Bejgarn S, MacLeod M, Bogdal C, Breitholtz M. Toxicity of leachate from weathering plastics: An exploratory screening study with Nitocra spinipes. Chemosphere 2015;132: 114-119.

10. Schwarzbauer J, Heim S, Brinker S, Littke R. Occurrence and alteration of organic contaminants in seepage and leakage water from a waste deposit landfill. Water Res. 2002;36: 2275-2287.

11. Trebouet D, Berland A, Schlumpf JP, Jaouen P, Quemeneur F. Traitement de lixiviats stabilisés de décharge par des membranes de nanofiltration. Revue des Sciences de I'Eau/J. Water Sci. 1998;11:365-382.

12. Foresti E. Perspectives on anaerobic treatment in developing countries. Water Sci. Technol. 2001;44:141-148.

13. García H, Rico J, García PA. Comparison of anaerobic treatment of leachates from an urban-solid-waste landfill at ambient temperature and at $35^{\circ} \mathrm{C}$. Bioresour. Technol. 1996;58: 273-277.

14. Sun H, Yang Q, Peng Y, Shi X, Wang S, Zhang S. Advanced landfill leachate treatment using a two-stage UASB-SBR system at low temperature. J. Environ. Sci. 2010;22:481-485.

15. Kettunen RH, Hoilijoki TH, Rintala JA. Anaerobic and sequential anaerobic-aerobic treatments of municipal landfill leachate at low temperatures. Bioresour. Technol. 1996;58:31-40.

16. Kettunen RH, Rintala JA. Performance of an on-site UASB reactor treating leachate at low temperature. Water Res. 1998;32:537-546.

17. Lin CY, Chang FY, Chang CH. Co-digestion of leachate with septage using a UASB reactor. Bioresour. Technol. 2000;73: 175-178.

18. Nkemka VN, Murto M. Biogas production from wheat straw in batch and UASB reactors: The roles of pretreatment and seaweed hydrolysate as a co-substrate. Bioresour. Technol. 2013;128:164-172. 
19. Montalvo S, San Martin J, Huiliñir C, Guerrero L, Borja R. Assessment of a UASB reactor with high ammonia concentrations: Effect of zeolite addition on process performance. Process Biochem. 2014;49:2220-2227.

20. Couras CS, Louros VL, Grilo AM, et al. Effects of operational shocks on key microbial populations for biogas production in UASB (Upflow Anaerobic Sludge Blanket) reactors. Energy 2014;73:866-874.

21. Kaparaju P, Serrano M, Angelidaki I. Optimization of biogas production from wheat straw stillage in UASB reactor. Appl. Energ. 2010;87:3779-3783.

22. Benyoucef F, Makan A, El Ghmari A, Ouatmane A. Solid household waste characterization and fresh leachate treatment: Case of Kasba Tadla city, Morocco. Environ. Eng. Res. 2015;20:363-369.

23. Rodier J. L'analyse de l'eau - eaux naturelles, eaux résiduaires, eau de mer. 9th ed. Paris, Dunod; 2009. p. 1365-1475.

24. Renou S, Givaudan JG, Poulain S, Dirassouyan F, Moulin P. Landfill leachate treatment: Review and opportunity. J. Hazard. Mater. 2008;150:468-493.

25. Vieira SMM, García AD. Sewage treatment by UASB-reactor. Operation results and recommendations for design and utilization. Water Sci. Technol. 1992;25:143-157.

26. Liu RR, Tian Q, Yang B, Chen JH. Hybrid anaerobic baffled reactor for treatment of desizing wastewater. Int. J. Environ. Sci. Technol. 2010;7:111-118.

27. Rajakumar R, Meenambal T, Banu JR, Yeom IT. Treatment of poultry slaughterhouse wastewater in upflow anaerobic filter under low upflow velocity. Int. J. Environ. Sci. Technol. 2011;8:149-158.

28. Nkemka VN, Murto M. Evaluation of biogas production from seaweed in batch tests and in UASB reactors combined with the removal of heavy metals. J. Environ. Manage. 2010;91: 1573-1579.

29. Zhang SJ, Liu NR, Zhang CX. Study on the performance of modified UASB process treating sewage. Adv. Mater. Res. 2013;610:2174-2178.

30. Singh L, Wahid ZA, Siddiqui MF, Ahmad A, Rahim MHA,
Sakinah M. Application of immobilized upflow anaerobic sludge blanket reactor using Clostridium LS2 for enhanced biohydrogen production and treatment efficiency of palm oil mill effluent. Int. J. Hydrogen Energ. 2013;38:2221-2229.

31. Li Y, Park SY, Zhu J. Solid-state anaerobic digestion for methane production from organic waste. Renew. Sust. Energ. Rev. 2011;15:821-826.

32. Gerardi MH. The microbiology of anaerobic digesters. New York: John Wiley \& Sons Inc.; 2003.

33. Makan A, Assobhei O, Mountadar M. In-vessel composting under air pressure of organic fraction of municipal solid waste in Azemmour, Morocco. Water Environ. J. 2014; 28:401-409.

34. Rizvi H, Ahmad N, Abbas F, et al. Start-up of UASB reactors treating municipal wastewater and effect of temperature/sludge age and hydraulic retention time (HRT) on its performance. Arab. J. Chem. 2015;8:780-786.

35. Raghab SM, El Meguid AMA, Hegazi HA. Treatment of leachate from municipal solid waste landfill. HBRC J. 2013; 9:187-192.

36. Iglesias JR, Castrillón Peláez L, Maranon Maison E, Sastre Andrés H. A comparative study of the leachates produced by anaerobic digestion in a pilot plant and at a sanitary landfill in Asturias, Spain. Waste Manage. Res. 2000;18:86-93.

37. Wiszniowski J, Robert D, Surmacz-Gorska J, Miksch K, Weber JV. Landfill leachate treatment methods: A review. Environ. Chem. Lett. 2006;4:51-61.

38. Kennedy KJ, Lentz EM. Treatment of landfill leachate using sequenching batch and continuous flow up-flow anaerobic sludge blanket (UASB) reactors. Water Res. 2000;34:3640-3656.

39. Chen S, Sun DZ, Chung JS. Simultaneous removal of COD and ammonium from landfill leachate using anaerobic-aerobic moving-bed biofilm reactor system. Waste Manage. 2007;28:339-346.

40. Fernández-Nava Y, Maranon E, Soons J, Castrillón L. Denitrification of wastewater containing high nitrate and calcium concentrations. Bioresour. Technol. 2008;99:7976-7981. 